\title{
Contents of Breast Milk Obtained from Mothers of Preterm and Term Newborn Infants
}

\section{Term ve Preterm Bebeklerin Anne Sütü Içeriği}

\author{
Demet Terek1, Özge Altun Köroğlu1, Eser Sözmen2, Mehmet Yalaz1, Nilgün Kültürsay1 \\ 1 Ege University Faculty of Medicine, Department of Pediatrics, Division of Neonatology, Izmir, Turkey \\ 2Ege University Faculty of Medicine, Department of Biochemistry, Izmir, Turkey
}

\begin{abstract}
Aim: We aimed to compare the macronutrient, antioxidant, insulin like growth factor 1 content of breast milk obtained from mothers of moderately premature and full-term infants.

Materials and Methods: In this prospective study mature breast milk samples were collected and frozen from mothers of moderately premature $(n=31$, gestational age $32.16 \pm 2.42$ weeks) and full term $(n=14)$ infants who were admitted to the neonatal intensive care unit. Frozen milk samples were thawed and macroonutrients (triglycerides, glucose, cholesterol, protein), antioxidants (TEAC: Trolox equivalent antioxidant capacity, FRAP: ferric reducing ability of plasma, TOA: total antioxidant activity), TBARS (ThioBarbituric Acid Reactive Substances) and insulin like growth factor 1 (IGF-1) levels were analysed.

Results: Macronutrient content, antioxidant properties, oxidative status and IGF-1 content of preterm and term breast milk were found similar. None of these parameters were related to necrotizing enterocolitis or achievement of total enteral feeds.

Conclusion: The donor milk obtained from mothers of term infants may be safely used for the moderately preterm infants cared in NICUs since both groups have similar breast milk properties.

Keywords: Areast milk, premature, term, antioxidant, insulin like growth factor 1
\end{abstract}

ÖZ

Amaç: Bu çalışmada amacımız term ve orta derecede prematüre anne sütünün makronutrien, antioksidan ve insülin benzeri büyüme faktörü-1 (IGF1) içeriği yönünden karşılaştırımasıdır.

Gereç ve Yöntemler: Bu prospektif çalışmada; yenidoğan yoğun bakımda yatan prematüre ( $n=31$, gestasyonel yaş $32,16 \pm 2,42$ hafta ) ve term $(n=14)$ bebeklerin anne sütü toplanarak dondurulmuştur. Dondurulmuş süt örnekleri çözülerek makronutrien (trigliserit, glukoz, protein ve kolesterol), antioksidan (TEAC: Trolox equivalent antioxidant capacity, FRAP: ferric reducing ability of plasma, TOA: total antioxidant activity), TBARS (ThioBarbituric Acid Reactive Substances) ve IGF-1 düzeyleri analize edildi.

Bulgular: Makronütrien, antioksidan, oksidan ve IGF-1 içeriği term ve preterm anne sütünde benzer olarak bulundu. Bu parametreler ile nekrotizan enterokolit ve total enteral beslenmeye başlama zamanı ile ilişki saptanmadı. Sonuç: Term bebeklerin anne sütünden oluşan donör anne sütü, term ve preterm anne sütünün içeriği benzer olduğu için orta derecede prematüre bebeklerde güvenle kullanılabilir.

Anahtar Kelimeler: Anne sütü, prematüre, matür, antioksidan, insülin benzeri büyüme faktörü 1

\section{Introduction}

Breastfeeding is strongly recommended because of its benefits for nutrition, improvement of gastrointestinal function, neurocognitive development and protection against acute and chronic diseases for all infants (1). Breast milk carries further importance for sick newborns, especially for its protective effects against necrotizing enterocolitis (NEC) for preterm infants $(2,3)$. However, disrupted mother-infant bonding for the premature infants admitted to neonatal intensive care units (NICU) negatively effects availability of breast milk. Therefore, clinicians caring for these critically 
ill infants in NICU, experience difficulty in the provision of adequate mother's milk (4).

In recent years human milk banking has become popular since donor milk is preferred over formula for the feeding of preterm infants in NICUs (5). Donor milk obtained from human milk banks usually consist of breast milk from mothers of full-term infants. We know that the content of human milk from mothers of premature and full-term infants may differ in various aspects. The duration and impact of these differences are not clearly stated in the current literature. Antioxidant content may be important since oxidant injury has a role in the pathogenesis of NEC (6). We also know that insulin like growth factor 1 (IGF-1) may be protective against $\operatorname{NEC}(7,8)$. As the needs of full-term and premature infants differ for optimal growth; macronutrient content of full-term milk may necessitate further modification when compared to premature milk with regard to antioxidant and IGF-1.

In this prospective study; we compared macronutrient, antioxidant, ThioBarbituric Acid Reactive Substances (TBARS showing oxidant status) and IGF-1 contents of human milk from mothers of premature and full-term infants admitted to our NICU. Infants were prospectively followed for early neonatal complications and feeding intolerance to find out if any of the studied content of breast milk had an association with these clinical parameters.

\section{Materials and Methods}

\section{Patients}

The study was conducted at the NICU of Ege University Children's Hospital. Mothers of premature and full-term infants admitted to NICU during the study period were consecutively enrolled. Mother-infant pairs with any contraindication against breast feeding (metabolic disease, maternal use of drugs not compatible with breast feeding) were exluded from the study. Smoking mothers and mothers of infants with any congenital malformation were also excluded. The study was approved by the local ethics committee (Ege University Faculty of Medicine Ethical Committee decision number: 11-7/24, on 18. Aug. 2011) and written informed consent was obtained from mothers enrolled in the study. All of the infants enrolled in this study were prospectively followed in our NICU until discharge.

Mothers were asked to provide milk samples at the $21^{\text {st }}$ postnatal day. Milk samples obtained by manuel expression of breasts were transferred immediately to the biochemistry laboratory on ice without any exposure to light in plastic tubes. All samples were stored at $-800 \mathrm{C}$ until sample collection was over. All milk samples were thawed and homogenized simultaneously for analysis. Analysis of macronutrient content of human milk. Triglycerides, glucose, cholesterol and protein contents of milk were analysed by commercially available kits. Analysis of IGF-1 content of human milk IGF-1 levels in the mother's breast milk were studied by ELISA according to the manufacturer's instructions (human IGF-1 Immunoassay kit, Assay Designs). The results are given as ng/g of protein.
Analysis of ThioBarbituric Acid Reactive Substances (TBARS): $0.4 \mathrm{~mL}$ of $8.1 \%$ sodium dodesil sulphate and $3 \mathrm{~mL}$ of $20 \%$ acetic acid were added to $0.4 \mathrm{~mL}$ of milk. After the addition of $3 \mathrm{~mL}$ of $0.67 \%$ thiobarbiturate, tubes were left in boiling water for one hour. Following cooling, tubes were centrifuged at $1.800 \mathrm{~g}$ for 1 minute and absorbance of the supernatant at $532 \mathrm{~nm}$ was measured spectrophotometrically by taking distilled water as basal value. The results are given as $\mathrm{nmol} / \mathrm{mL}$ (9).

Analysis of antioxidant content of human milk: Trolox equivalent antioxidant capacity (TEAC); ABTS (2,2'-azinobis3ethylbenzthiazolinesulfonate) $(7 \mathrm{mmol} / \mathrm{L})$ and potassium persulphate $(4.95 \mathrm{mmol} / \mathrm{L})$ were mixed $(1 / 1: \mathrm{v} / \mathrm{v})$ and stored in room temperature for at least $12 \mathrm{~h}$ before using. This reactive was diluted by phosphate buffer and mixed with 5-25 microliter milk and absorbances were read in $734 \mathrm{~nm}$ vawelenght in a spectrophotometer. Phosphate buffer and trolox were used as control and standart, respectively (10).

Ferric reducing antioxidant power (FRAP): Mixing solution $(10: 1: 1, \mathrm{v} / \mathrm{v} / \mathrm{v})$ of acetate buffer $(10 \mathrm{mM}, \mathrm{pH}=3.6)$, $(2,4,6$ tripyridyl-s- triazine TPTZ) $(10 \mathrm{mM})$ and $\mathrm{FeCl} 3(20$ $\mathrm{mM}$ ) were added into milk sample and stored in room temperature for $30 \mathrm{~min}$. Readings were done in $620 \mathrm{~nm}$ in a microplate reader (11).

Total antioxidant activity (TAA): The solution of $0.1 \mathrm{mM}$ DPPH (1.1-diphenyl-2-pikrylhydrazin) was rapidly mixed well with serum sample $(1 / 100 ; \mathrm{v} / \mathrm{v})$. The decline in absorbance was recorded at $550 \mathrm{~nm}$ against ethanol blank over a period of 20 min with 5-minute intervals in a microplate reader. The decrease of absorbance corresponding to $100 \%$ radical scavenging was determined with a solution of pyrogallol in DMSO (ca. 0.5\%) which caused complete scavenging within seconds (12).

\section{Statistical Analysis}

Data are summarized as mean \pm SD and percentages. Statistical Package for the Social Sciences for Windows 19.0 (IBM Corporation, Armonk, NY, USA) was used to evaluate the data. Shapiro-Wilk test was used to evaluate the normality of the data. Chi-square test, Fischer exact test, Independent samples t-test (with 95\% confidence interval) tests were used to compare the two groups. Pearson correlation test was used to explore the relationship of milk contents with clinical outcome. We considered differences significant at $\mathrm{p}<0.05$.

\section{Results}

Antenatal and clinical characteristics of the study groups: Antenatal and clinical characteristics of the study groups are given in Table I.

Infants in the preterm and term groups had mean (SD) birth weight of 1737.10 (538) gram vs. 3359 (570) gram $(p<0.001)$. Mean (SD) gestational ages for preterm and term groups were 32.16 (2.42) vs. 38.79 (1.12) weeks 
$(p<0.001)$. Twenty seven $(87.1 \%)$ infants in the preterm group and $12(85.7 \%)$ infants in the term group were born via $C / S(p=1.00)$. Total enteral feeds were achieved at 15.27 (13.52) days vs. 1.69 (1.03) days in preterm and term groups respectively $(p<0.001)$. Six infants in the preterm group had NEC, one of whom was operated on. None of the infants in the term group was diagnosed with NEC, as expected.

Macronutrient, antioxidant and IGF-1 content of human milk: Analysis of milk samples from the study groups is shown in Table II. Protein, trygliceride, glucose and cholesterol content of milk samples from the preterm group were similar with the term group. TBARS, TEAC, FRAP and TAO measurements were also similar, and IGF-1 content of the milk did not differ among the groups.

Clinical outcome and milk contents: When we compared the content of preterm human milk samples from mothers of infants with NEC to milk samples from mothers of infants without NEC; we did not see any difference in any of the parameters analysed in this study (data not presented here, all $p$ values $>0.005$ ). None of the studied contents of human milk showed any correlation with the postnatal age at which total enteral feeds were achieved.

\begin{tabular}{|l|l|l|l|}
\hline \multicolumn{4}{|l|}{ Table I. Clinical characteristics of the study population } \\
\hline Cinical characteristics & Preterm $(\mathbf{n = 3 1 )}$ & Term $(\mathbf{n = 1 4 )}$ & $\mathbf{p}$ \\
\hline Birth weight $(\mathrm{g})^{*}$ & $1737.10(538)$ & $3359.29(570)$ & $<0.001$ \\
\hline Gestational age (weeks) & $32.16(2.42)$ & $38.79(1.12)$ & $<0.001$ \\
\hline $\mathrm{C} / \mathrm{S}^{\dagger}$ & $27(87.1)$ & $12(85.7)$ & 1.00 \\
\hline Male gender ${ }^{\dagger}$ & $18(58.06)$ & $10(71.42)$ & 0.513 \\
\hline $\begin{array}{l}\text { Achievement of full } \\
\text { enteral feeding (days) }\end{array}$ & $15.27(13.52)$ & $1.69(1.03)$ & $<0.001$ \\
\hline
\end{tabular}

*Data given as mean (SD), 'Data given as number (\%), SD: Standard deviation, C/S: Cesarean section

Table II. Analysis of milk samples from study groups, (data given as mean \pm SD)

\begin{tabular}{|l|l|l|l|}
\hline & Preterm $(\mathbf{n = 3 1})$ & Term $(\mathbf{n = 1 4 )}$ & $\mathbf{p}$ \\
\hline Protein $(\mathrm{mg} / \mathrm{mL})$ & $1.83 \pm 0.56$ & $1.64 \pm 0.35$ & 0.243 \\
\hline Trygliceride $(\mathrm{mg} / \mathrm{dL})$ & $703.84 \pm 473.62$ & $712.73 \pm 280.21$ & 0.948 \\
\hline Glucose $(\mathrm{mg} / \mathrm{dL})$ & $71.87 \pm 25.90$ & $70.13 \pm 17.26$ & 0.820 \\
\hline Cholesterol $(\mathrm{cm})$ & $285.51 \pm 33.63$ & $276.83 \pm 18.36$ & 0.372 \\
\hline TBARS $(\mathrm{nmol} / \mathrm{mL})$ & $4.55 \pm 1.93$ & $4.28 \pm 1.08$ & 0.626 \\
\hline TEAC $(\mathrm{mmol} / \mathrm{mL})$ & $28.93 \pm 8.88$ & $29.10 \pm 4.42$ & 0.934 \\
\hline FRAP $(\mathrm{mmol} / \mathrm{mL})$ & $1.01 \pm 0.38$ & $1.11 \pm 0.35$ & 0.384 \\
\hline TA0 $(\mathrm{mmol} / \mathrm{mL})$ & $1.01 \pm 0.83$ & $1.11 \pm 0.74$ & 0.712 \\
\hline IGF1 $(\mathrm{ng} / \mathrm{gr})$ & $0.20 \pm 0.05$ & $0.23 \pm 0.07$ & 0.215 \\
\hline
\end{tabular}

TBARS: ThioBarbituric Acid Reactive Substances, TEAC: Trolox equivalent antioxidant capacity, FRAP: Ferric reducing antioxidant power, TOA: Total antioxidant activity, IGF1: Insulin like growth factor 1

\section{Discussion}

Providing breast milk for sick newborns is important for the prevention of feeding intolerance, necrotizing enterocolitis and systemic infections (1). When the mother cannot directly breastfeed the infant; mother's own milk can be expressed, frozen and stored to be ready when needed. Donor human milk is suggested as the first alternative when mother's own milk is not avaliable (5). Storage and process of human milk may cause changes in the composition of the milk. In addition to that, donor human milk is collected form mothers of term infants. Since the needs of term and preterm infants differ; the composition of human milk from mothers of term infants also differ.

In this study we compared macronutrient and antioxidant properties of human milk in addition to IGF-1 content from human milk samples of preterm and term newborns' mothers.

In this study human milk from mothers of preterm and term newborns had similar protein, trygliceride, glucose and cholesterol content. Bauer and Gerss (13) has analysed the macronutrient and mineral content of human milk produced by mothers of preterm infants. In their study population, including mothers of extremely preterm infants with gestational ages below 28 weeks, human milk from the preterm group had higher protein, carbohydrate, fat and energy content when compared to the term group. They have also demonstrated the longitudinal decline in the protein content of both preterm and term human milk. Protein content of preterm human milk was lower in the samples obtained from mothers of infants with lower gestational ages. During the 8 weeks of lactation, the protein content of extremely preterm human milk $(<28$ weeks) was $2.3 \pm 0.5 \mathrm{~g} / \mathrm{dL}$, whereas severely preterm human milk (28-31 weeks) had $2.1 \pm 0.3 \mathrm{~g} / \mathrm{dL}$, moderately preterm human milk (32-33 weeks) had $1.9 \pm 0.3 \mathrm{~g} / \mathrm{dL}$ and term human milk had $1.6 \pm 0.4 \mathrm{~g} / \mathrm{dL}$ average concentration of protein. Human milk from our preterm group with a mean gestational age of $32.16 \pm 2.42$ weeks had a similar protein content of $1.83 \pm 0.56 \mathrm{~g} / \mathrm{dL}$ when compared to the similar gestational age group in Bauer's study. The protein content of our term human milk samples was insignificantly lower, as $1.64 \pm 0.35 \mathrm{~g} /$ $\mathrm{dL}$. Absence of extremely preterm infants' mothers from our study population may have caused the failure to demonstrate the differences in the macronutrient content of preterm and term human milk.

TBARS (showing the oxidant status) and TEAC, FRAP, TAO (showing the antioxidant properties), measurements of preterm and term human milk samples were similar in this study. Antioxidant properties of preterm and term human milk has been the focus of interest in a limited number of studies in the literature. Our data is consistent with the observations of Friel et al. (14) and Sandal et al. (15) who also found similar antioxidant properties of preterm and term human milk. On the other hand Quiles et al. (16) has shown that total antioxidant capacity of preterm human milk was lower than term human milk, in accordance with Coenzyme Q concentration. 
IGF-1 content of preterm and term human milk were found similar in two studies like ours in the past $(17,18)$. Nagashima et al. (17) has demonstrated that the IGF-I content in human milk was not affected by gestational age or birth weight and was higher than cow's milk. Elmlinger et al. (18) compared the insulin like growth factors and their binding proteins in human milk samples from preterm and term newborns' mothers; and showed that mean concentrations of these growth factors and binding proteins did not change in the two groups. However, in another study where four different angiogenic factors were studied in preterm and term human milk; authors have concluded that IGF-1 concentrations were higher in milk samples obtained from mothers who delivered preterm than those of mothers of term neonates, so was the vascular endothelial growth factor and basic fibroblast growth factor (19). Analysis of frozen milk samples may be a limitation; since freezing and thawing may also effect the results.

The limitation of the study is the lack of the extremely preterm infants group. Therefore, we could only compare term and moderately preterm infant groups. However, we compared different bioactive components in both groups, which is the powerful side of the study.

Contents of breast milk may differ from mother to mother, during phases of lactation and as the infant grows. Preterm human milk may also differ in many aspects when compared to term human milk. However, in our study we did not observe any significant difference in macronutrient, antioxidant, TBARS and IGF-1 content of preterm and term human milk. We also did not see any correlation of these parameters with NEC and achivement of full enteral feeds. Our data, therefore, support the idea that the donor milk obtained from mothers of term infants may be safely used for the moderately preterm infants cared for in NICUs since their macronutrient and antioxidant properties together with IGF-1 levels are similar. However, further studies considering human milk properties of extremely preterm infants are necessary.

\section{Acknowledgements}

We acknowledge Prof. Mehmet Orman from the department of biostatistics, Ege University Faculty of Medicine, for his assistance with the statistical analysis.

\section{Authorship Contributions}

Ethics Committee Approval: The study were approved by the Ege University of Local Ethics Committee, Informed Consent: Consent form was filled out by all participants, Concept: Nilgün Kültürsay, Design: Nilgün Kültürsay, Mehmet Yalaz, Data Collection or Processing: Demet Terek, Eser Sözmen, Analysis or Interpretation: Özge Altun Köroğlu, Nilgün Kültürsay, Literature Search: Demet Terek, Özge Altun Köroğlu, Writing: Özge Altun Köroğlu, Demet Terek, Peer-review: Externally peer-reviewed, Conflict of Interest: No conflict of interest was declared by the authors, Financial Disclosure: The authors declared that this study has received no financial support.

\section{References}

1. Section on Breastfeeding. Breastfeeding and the use of human milk. Pediatrics 2012; 129: 827-41.

2. Menon G, Williams TC. Human milk for preterm infants: why, what, when and how? Arch Dis Child Fetal Neonatal Ed 2013; 98: 559-62.

3. Bhatia J. Human milk and the premature infant. Ann Nutr Metab 2013; 62(Suppl 3): 8-14.

4. Kim JH, Chan CS, Vaucher YE, Stellwagen LM. Challenges in the practice of human milk nutrition in the neonatal intensive care unit. Early Hum Dev 2013; 89(Suppl 2): 35-8.

5. ESPGHAN Committee on Nutrition, Arslanoglu S, Corpeleijn W, et al. Donor human milk for preterm infants: current evidence and research directions. J Pediatr Gastroenterol Nutr 2013; 57: 535-42.

6. Lee JW, Davis JM. Future applications of antioxidants in premature infants. Curr Opin Pediatr 2011; 23: 161-6.

7. Ozen $S$, Akisu M, Baka M, et al. Insulin-like growth factor attenuates apoptosis and mucosal damage in hypoxia/ reoxygenation-induced intestinal injury. Biol Neonate 2005; 87: 91-6.

8. Baregamian N, Song J, Jeschke MG, Evers BM, Chung DH. IGF-1 protects intestinal epithelial cells from oxidative stressinduced apoptosis. J Surg Res 2006; 136: 31-7.

9. Stupans I, Kirlich A, Tuck KL, Hayball PJ. Comparison of radical scavenging effect, inhibition of microsomal oxygen free radical generation, and serum lipoprotein oxidation of several natural antioxidants. J Agric Food Chem 2002; 50: 2464-9.

10. Re R, Pellegrini N, Proteggente A, Pannala A, Yang M, Rice-Evans C. Antioxidant activity applying an improved ABTS radical cation decolorization assay. Free Radic Biol Med 1999; 26: 1231-7.

11. Pulido R, Bravo L, Saura-Calixto F. Antioxidant activity of dietary polyphenols as determined by a modified ferric reducing/ antioxidant power assay. J Agric Food Chem 2000; 48: 3396402.

12. Yıldırım HK, Akçay $Y D$, Güvenç $U$, Altındişli $A$, Sözmen $E Y$. Antioxidant activities of organic grape, pomace, juice, must, wine and their correlation with phenolic content. Int J Food Sci Technol 2005; 40: 133-42.

13. Bauer J, Gerss J. Longitudinal analysis of macronutrients and minerals in human milk produced by mothers of preterm infants. Clin Nutr 2011; 30: 215-20.

14. Friel JK, Martin SM, Langdon M, Herzberg GR, Buettner GR. Milk from mothers of both premature and full-term infants provides better antioxidant protection than does infant formula. Pediatr Res 2002; 51: 612-8.

15. Sandal G, Uras N, Gokmen T, Oguz SS, Erdeve O, Dilmen U. Assessment of oxidant/antioxidant system in newborns and their breast milks. J Matern Fetal Neonatal Med 2013; 26: 540-3.

16. Quiles JL, Ochoa JJ, Ramirez-Tortosa MC, et al. Coenzyme $\mathrm{O}$ concentration and total antioxidant capacity of human milk at different stages of lactation in mothers of preterm and full-term infants. Free Radic Res 2006; 40: 199-206.

17. Nagashima K, Itoh K, Kuroume T. Levels of insulin-like growth factor $I$ in full- and preterm human milk in comparison to levels in cow's milk and in milk formulas. Biol Neonate 1990; 58: 343-6.

18. Elmlinger MW, Hochhaus F, Loui A, Frommer KW, Obladen M, Ranke MB. Insulin-like growth factors and binding proteins in early milk from mothers of preterm and term infants. Horm Res 2007; 68: 124-31.

19. Ozgurtas T, Aydin I, Turan O, et al. Vascular endothelial growth factor, basic fibroblast growth factor, insulin-like growth factor-I and platelet-derived growth factor levels in human milk of mothers with term and preterm neonates. Cytokine 2010; 50: $192-4$. 